\title{
The Importance of Migrant Workers Protection in Industrial Revolution Era 4.0 (Comparative Study between Indonesia and Philippines)
}

\author{
Fitria Ariyanti ${ }^{1}$, Lina Miftahul Jannah ${ }^{2}$ \\ fitrigani.fg@gmail.com¹,miftahul@ui.ac.id² \\ Public Administration, Faculty of Administrative Science, University of Indonesia, Depok, Indonesia ${ }^{1}$ \\ Public Administration, Faculty of Administrative Science, University of Indonesia, Depok, Indonesia ${ }^{2}$
}

\begin{abstract}
The changes triggered by the rise of industrial revolution 4.0, has forced the government to improve the protection of migrant workers, especially Indonesia and Philippines as the two biggest senders of migrant workers among ASEAN member countries. This paper aims to compare protection migrant workers in industrial revolution 4.0 era that given by Philippines and Indonesia. This paper is using qualitative method, by collecting data through literature studies. The analysis result showed that in terms of regulation, Indonesia and Philippines have allocated considerable attention to protect the migrant workers. On the level of program, the government and non-governmental organization has initiated the making of a digital platform to help the migrant workers in sharing various information. The using digitalization as migrant workers' protection means is showed by each country through the use of digital-based platform initiated by the government and non-governmental Organization.
\end{abstract}

Keyword: Migrant Worker, Protection, Industrial Revolution

\section{Introduction}

The recent development of industrial sector which is introduced by industrial revolution 4.0 makes significant changes in all human life activities. The changes of manual into digital form actually affects the changes in market needs upon workers. It cannot be denied that a country needs workers. This is because workers have the role and position to achieve the goal of a country national development [1]. Factors of economy, limited job vacancy, and difference between domestic and abroad salary encourage the worker to find job abroad [2].

According to the data from World Economic Forum (2018) recently there are 258 millions of international migrants [3]. Furthermore, Miroslav Lajčák (2018), stated that statistical changes on migrants are accompanied by demographic change, technology advance, developing workers' market needs, as well as challenges caused by war, shortages, human rights abuse and climate change [3]. The large number of migrants is mostly occupied by workers. According to International Labour Migration (ILO), in 2017, migrant workers contribute fifty-nine percent of all international migrant population in the world [4]. This 
shows that there are quite a lot of people who mobilized abroad to find a job due to various factors.

In 2017, there was eight percent of migrants who came from ASEAN countries and increased by six percent in 1995 [5]. Due to the rapid development of intraregional global migration among ASEAN countries, leading some countries to grow as migrant workers sender countries and a center of migrant workers acceptor. Furthermore, Testaverde and colleagues (2017) also stated that Cambodia, Indonesia, Lao People's Democratic Republic, and Myanmar are the countries of main workers sender source both to ASEAN and other countries [5]. The migrant workers from sender countries that be mentioned before also migrate to other country in Southeast Asia, especially to Malaysia, Singapore, and Thailand. In addition to Southeast Asia, they also sent the workers migrant to the Middle East, Europe and America [6].

In this article, the authors focused on two migrant worker sender countries, which are Indonesia and Philippine which belong to ASEAN countries which send quite a lot of migrant workers. In 2018, the number of Philippines migrant workers are greater than Indonesian migrant workers, with greater female migrant workers than male migrant workers. The following Table 1 shows the comparison of Indonesian Migrant Workers (PMI) and Overseas Filipino Worker (OFW) in 2018.

Table 1. Comparison of PMI and OFW Number

\begin{tabular}{rcc}
\hline & Indonesia & Philippine \\
\hline Male & 84,665 & $1,016,000$ \\
Female & 198,975 & $1,284,000$ \\
Total & $\mathbf{2 8 3 , 6 4 0}$ & $\mathbf{2 , 2 9 9 , 0 0 0}$ \\
\hline
\end{tabular}

Source: Puslitfo BNP2TKI [7] and Phillippine Statistics Authority [8], 2018.

The transmission of migrant workers on one side actually affects positively in the form of the emergence of remittance. For the developing countries such as Indonesia and Philippine, remittance is an important external capital source of income and the country's main foreign exchange [9]. The sending of Overseas Filipino Worker which is more than Indonesia Migrant Workers also affect the remittance received by each country. In 2018, Indonesia received remittance as much as 10,97 Million USD [10], while Philippine was as much as $\$ 34$ Billion [11]. According to the data, it can be seen that Philippine remittance is still more than Indonesia, with difference of 23,03 billion US\$. Remittance received by Philippine in 2018 made the Philippine in the top five ranks as the country with the biggest remittance acceptance[12].

On one side, migrant workers transmission also emerges challenges especially in the recent industrial revolution era. The emerged change of industrial revolution affects the omission of several job sectors, but also potentially create business and job opportunity for the migrants which never there before [13]. The omission of several job sectors mainly occurs in low-level job sectors such as domestic workers or factory workers. According to McKenzie (2017), in his research entitled "The Fourth Industrial Revolution and International Migration", he mentioned that there are several factors which have small and big potential to be digitalized, as seen in the following table 2 . 
Table 2. Job Sectors Which Have The Potential To Be Digitalized

\begin{tabular}{|c|c|}
\hline $\begin{array}{c}\text { Sectors with the Biggest Potential to be } \\
\text { Digitalized }\end{array}$ & $\begin{array}{c}\text { Sectors with the Smallest Potential to be } \\
\text { Digitalized }\end{array}$ \\
\hline Accommodation Service and Food & Health Treatment and Social Assistance \\
\hline Factory & Information \\
\hline Agriculture & Professional \\
\hline Transportation and Warehousing & Management \\
\hline Retail Trade & Educational Service \\
\hline
\end{tabular}

Source: McKenzie, 2017 [14].

The potential loss of some of these employment sectors, as shown in Table 2, will lead the countries to improve the competence of its workforce. Digitalization in several employment sectors is a challenge and also an opportunity for migrant workers. According to Walwei (2016), in the case of capital-skill complementarity, the demand for highly skilled workers performing creative tasks will increase further, while low-skilled workers in comparison are most likely to lose their job ("skill-biased technological change") [15]. From this case, low-skilled migrant workers must be under the pressure to find work aboard, because of the tight competition. If the domestic jobs are gone and limited, this may create pressure for lower domestic workers to leave their home country and find work abroad. Furthermore, Mårten Blix argued that digitalization is changing many aspects of work, job security, and wages; and without policies to adapt, inequality could increase further [16]. One of the challenges of this digitalization is multiple uncertainties, as these impacts are not limited to potential job losses or job gains [15]. According to the Chang and Huynh (2016), popular countries who send workers abroad, namely are five ASEAN member countries including Cambodia, Indonesia, Philippine, Thailand, and Vietnam which contribute about 80 percent of all ASEAN workers, have the potential to digitize of approximately fifty six percent of all job sectors within one or two future decades [17]. The digitalization of these countries is a challenge, policies are needed to improve the ability of migrant workers.

Challenges for the migrant workers are not only in terms of the digitalization in several job sectors, but also in the migrant workers' life activities. This is due to Internet of Things which is introduced in industrial revolution 4.0 affecting every facet of migrant workers' experience, starting from how they search for the job, to their relationship with family and friend, supervision of their workplace, and advocacy which they and other people can do to improve the condition of their workplace [18]. Job searching for the migrant workers in this digitalization era is easier and grows rapidly with the assistance of social network including online website and social media. However, not all information obtained from online websites and social media are true. This is because in the recent digitalization era, criminal action also develops through the Internet of Things. According to Alcácer and Cruz-Machado (2019), in industrial revolution 4.0, there are many devices connected to global networks through the internet annually [19]. As the connected device increases, the cyber-attack also increases. Cyber-attack or cybercrime or crime through the internet also affect the cases experienced by migrant workers, such as job vacancy fraud abroad in a website or social media as well as online migrant trade case.

In Indonesia, the case of international job vacancy fraud has become a popular phenomenon. In 2018, Migrant Care, a local NGO focusing on migrant workers issue, has received ten complains about job fraud [20]. Furthermore, in the early 2019 (between JanuaryJuly), The Indonesian Migrant Workers Union (Serikat Buruh Migran Indonesia), have received complaints from thirty-four Indonesian prospective migrant workers from Indramayu 
fooled by job vacancy advertisement posted in social media [21]. As many as twenty-four people were promised to be working in Taiwan, seven people to South Korea, and three people to Japan, but none of them really got there with a total loss of more than 300 million rupiahs [21]. Other cases experienced by Indonesian migrant workers which seized the public attention was the human trafficking case, where Indonesian migrant workers were found to be advertised for sale through online trade sites in Singapore [22]. A similar case also occurs to Indonesian migrant workers who work in Malaysia who are advertised through the status of one of the popular social media, which is Facebook [23].

Similar to Indonesia, online job vacancy fraud also happens in Philippine. According to the report made by Philipines Overseas Employment Administration (POEA), job vacancy fraud abroad case in Philippine happens in a group of Facebook social Media named "Now Hiring Work Abroad 2018" which offered various jobs for various position in United States of America, Canada, England, Japan, New Zealand, Australia, and other countries [24]. Such fraud is capitalized with high wages, high overtime wages, paid vacation leave, free transportation, as well as free meal and accommodation. However, the applicants received an email informing them that there must transfer Php9,800.00 to the Philippine bank account in 48 hours (told as the cost of visa) following their accepted application [24]. POEA ensured that such a thing is job vacancy fraud. This can be seen that the development of digital access also affects the migrant workers negatively, one of them is the job offer fraud abroad cases which recently is growing.

The recent rapid development of the industry must be utilized by the government to improve protection for migrant workers. This is aiming to minimalize the cases that have been explained above since problems experienced by migrant workers will always exist as the current development. It is particularly for the Indonesian and Philippine Government which must release policy according to the demand for the recent development. This policy must involve international condition in the form of visa agreement, cooperation in providing skill training, and the protection of migrant workers' rights [14]. The protection of migrant workers is the most essential part from the government so that the migrant workers can work safely and comfortably both before they go abroad, during their stay abroad, and when they are back from abroad. Good protection for migrant workers indirectly affects the increase of migrant workers' competence, so that it will also affect the remittance sent to each country that sends the migrant workers.

International Organization for Migration (2017) argued that migration has helped the lives of people both in the original and target countries as well as has offered opportunities to millions of people in the world to live safely and significantly abroad [2]. International Organization for Migration (2017), also added that migration has become the most important part since the presence of globalization which causes borderless amount countries [2]. In line with that, Irianto, et al (2011) states that migration is a life survive strategy, considering that many migrations were done due to economical reason [25]. Bhopal argued that throughout the history of people become migrant, and with the absolute number of migration, the recent number is bigger than before [26]. Kleiner mentioned that migration can be caused by various migrant including immigrant, emigrant, refugee, seasonal worker, guest worker, businessman, diplomat, students' exchange, and specialist [27]. According to those several experts' opinions, it shows that migration is a natural thing done by a human, one of them is migrating to find a job due to economical reason.

Migrant workers (both seasonal workers and guest workers) must be given protection. According to Arisman and Jaya (2018), migrant workers are often considered a cheap and flexible workers who can be exploited. Migrant workers' right often becomes the 
second after economic benefit they bring to the original country (by providing cheap worker) and target country (through remittance which is quite large) [28]. Meanwhile, migrant workers are really needed by a country. Ruhs and Anderson (2010) argued that businessmen often claim that they need migrant workers to fill the shortage of worker's skills and/or to do the job which cannot be done by the local people during the economic development, although it is actually not only during economy development [29]. According to that explanation, the need of migrant workers becomes important, so that the protection also needed to complement the migrant workers' rights, since they are often recognized as cheap workers which can be exploited.

It is particularly in recent industrial revolution era 4.0 which changes the activities related to migration and the global workers market. According to World Economic Forum (2017), industrial revolution 4.0 changes migration and its perception outside the implication observed before [13]. Such changes can be from the migration management and border control to direct migration path and facilitate the migrant integration, so that it must see the significant change on migration policy and practice in the future decade as the specific result of industrial revolution 4.0 technology. Lee, et al (2018), argued that the fourth industrial revolution concept can be defined as revolutionary changes based on various recent technology which does not describe the technical paradigm uniformly [30]. According to Farbenblum, Berg, and Kintominas (2018), the determination of minimum workers' standard in the original country and other legal protection often lacks [31]. Industrial revolution 4.0 encourages the development of digital platform development to connect and manage the workers and make it possible for them to share their experience and strategy, and collectively advocate better condition, as well as industrial revolution 4.0 development encourages the government and civil organization to also find technological solution to overcome the obstacles faced by the migrant workers who want to file complaint and find solution [31]. Based on this literature review, industrial revolution 4.0 encourages the existence of digitalization in giving protection to the migrant workers, since traditional protection (offline) often lacks, so that the government, civil society organization and migrant workers must find the opportunity of the industrial revolution themselves in order to give the migrant workers protection. Based on such problems, then this article writing formulates the following problem:

- How do Philippine and Indonesia provide protection to migrant workers in the industrial revolution 4.0 era?

\section{Methodology}

This journal article writing used a qualitative method which is a literature study. The writer used this method to answer the research question which becomes the focus of this paper, which is the protection of migrant workers of comparative study between Indonesia and Philippine. The writer was periodically read and analyzed journal, article and other document sources related to the paper theme.

This method was used to analyze the protection of migrant workers' protection comparisons in Indonesia and the Philippines. These two countries become the focus of this paper for the comparison, since they are countries which have send quite large number of workers abroad. This writing focused on the protection given by the government entity to each country and other non-governmental organization, in the middle of the industrial revolution 
4.0 which change the workers' market globally. Comparative study between Indonesia and Philippine in giving protection to the migrant workers in industrial revolution 4.0 era was analyzed by using two aspects, those are:

1. Regulation becomes the legal protection of the migrant workers from the original country.

2. The program that has used digitalization to give protection to the migrant workers in the industrial revolution 4.0 era.

These two aforementioned aspects give a description regarding the migrant workers' protection given by the two countries, so that the difference and similarity between two countries in giving protection can be seen, especially in using a digital system which rapidly develops during the recent industrial revolution 4.0.

\section{Result and Discussion}

Migrant workers' protection always exists along with the placement of migrant workers. The migrant workers' protection must be given even before the workers reach the target country, starting from the migrant worker search for the job until they come back to the original country. Before we discussed to protection that both countries provide from regulation and program, author show history about migraine worker in both country, Indonesia and Philippines based on migrant worker job sector.

\section{History of the Development of Migrant Workers in Indonesia and Philippine}

Indonesia workers transmission abroad cannot be separated from the past Indonesia experience. Indonesia's first transmission of workers abroad was in 1890 during Dutch-East Indies Colonial. There were as many as 32,986 workers were sent to Suriname and South America which were the colonial country of Dutch to be employed as farm labors [32]. In 2004, migrant workers' placement is mostly on informal sectors such as house assistance, baby sitter, and nurse for the elderly [33]. The workers' transmission in this sector is dominated by female migrant workers. Along with the development, recently there are many formal job sectors such as shop/restaurant/hotel workers, construction workers, factory worker, chefs, and cruise ship workers [5]. The changes of job sectors into more formal are also encouraged by the program of Government to Government given by the Indonesia government started in 2006. Indonesia government through Directorate of Migrant Workers Placement and Protection (Direktorat Penempatan dan Perlindungan Tenaga Kerja Luar Negeri/ PPTKLN) under general directorate of PPTKLN of Ministry of Manpower and Transmigration conducted Indonesia migrant workers' placement through Government to Government ( $G$ to $G$ ) program to South Korea [34]. Placement through the government to government scheme experiences development by the additional of cooperation with Japan in 2008 , by opening job vacancy as a hospital nurse and elderly nurse [34]. Recently, job sectors fulfilled by Indonesia migrant workers becomes varied, starting from informal to formal sector.

The placement of Overseas Filipino Worker, is not also separated from the history of Philippine which was colonized by Spain. It was first conducted in 1565 during the Spain colonization in which there were the many Philippines forced by Spain to work as a sailor in trade ship to the New World. In 1899, the Philippines migrated as a worker in the agricultural 
and service sectors in the United State of America. In the 1930s, about 50,000 Philippines migrated to Hawaii and West Coast to work as farmer in an agricultural farms. According to Gonzalez III (1998), around the end of the 1980s to the beginning 1990s, Overseas Filipino Worker has general characteristics which were easy to be recognized [35], those are:

- The male migrant workers were the workers at service or care service, who were employed in Middle East countries (possibly in Saudi Arabia), they were most likely married and had a child. Male migrant workers were recruited in National Capital City area but can also from village outside Manila (especially Ilocos area), they are also most likely young man aged between 25-44 years old.

- Female migrant workers were workers employed as both entertainers in Japan or housemaid in Singapore, Hong Kong, or Middle East, most likely single but can also be married ad had children. Female migrant workers were recruited well from poor village area outside Manila, aged younger than the male migrant workers, which was 15-34 years old.

The recent development also changes the interest of Overseas Filipino Worker to work in more formal sectors. In 2013, Overseas Filipino Worker mostly works in job sectors such as housemaid, professional nurse, and caregiver for those who worked at land, while sailor job sectors employ almost 340,000 OFWs [36]. In 2016, based on data from Philippine Overseas Employment Administration (POEA), job sectors which are were demanded by Overseas Filipino Worker were professional specialization jobs such as technic which contributes $26 \%$ of the total OFW job [36]. Other specialization jobs which were quite demanded is general job (driver, electrical worker, clearer), hospitality, nurse and medical assistance, assistance, production operation, personal care, sale, administration, art/creative/graphical design, pediatrician and obstetrician, OB public relationship/ communication, Plane Maintenance, Law Service, Education/Training \& Development, Quality/ Assurance Control, related to IT, and Architecture/ Interior Design [36]. In 2018, job sectors demanded by Overseas Filipino Worker were job in health sector (nurse, doctor), technic, and general job (driver, electrical worker, clearer), manufacture/production, IT, education and business marketing/development, work based on sea (sailor or ship engineer) as well as specialization in engineering and service of Food/Beverage/Restaurant [37]. If it is compared to Indonesia, Philippine is way more excellent in terms of migrant workers' placement, since most of the Philippine migrant sectors are in more formal and specialized job. However, Indonesia has done several advancements in terms of migrant workers' placement, in which it starts to enter the formal sectors such as caregiver, chef, and others.

\section{Regulation which Becomes the Legal Protection of the Migrant Workers}

The regulation foundation of migrant workers' protection in Indonesia and the migrant workers' placement experience changes along with its development. The regulation which becomes the legal protection was firstly issued in 1970, which is Government Regulation No. 4 of 1970 setting the workers' placement through the Program of between Job and between Region (Program Antarkerja Antardaerah/AKAD) as well as between job and between countries (Antarkerja Antarnegara/AKAN) [32]. Furthermore, this regulation changed in 2004, by the issuance of Law No. 39 of 2004 regarding Indonesia Workers' Placement and Protection Aboard to emphasize the Indonesian Workers' placement and Workers [40]. In 2017, government-issued the Law No. 18 of 2017 regarding Indonesia Migrant Workers' Protection which was the change of the Law No. 39 of 2004 regarding Indonesian Workers Placement and Protection Abroad, since the Law is not in accordance with the need development of Indonesia migrant workers' protection. The change of 
regulation which becomes legal protection for Indonesian migrant workers experience several amendments because the regulation needs to be in accordance with the recent development. Between one regulation with the other regulation needs to complement each other.

In the new regulation, which is the Law Number 18 of 2017, regarding Indonesian Migrant Working's Protection, it emphasizes more on the migrant workers' protection [41]. The protection given to the Indonesian Migrant workers are:

- Protection before working is all activities to give protection starts from the registration until departure. Protection that must be given before working is on Article 8 paragraph 1 to 3 . Protections that can be given are:

- Administrative protection includes:

a. Completeness and legality of placement document; and

b. Determination of job conditions and requirements.

- Technical protection includes:

a. Provision of information socialization and dissemination;

b. Improvement of quality of Indonesian Migrant Workers Prospective through education and work training;

c. Social Insurance;

d. Facilitating the fulfillment of Indonesian Migrant Workers Prospective' Right;

e. Encouragement of the introductory functional employees' role;

f. Placement service in one roof-integrated service of placement and protection of Indonesian Migrant Workers' Protection; and

g. Coaching and supervision.

- Protection during working is all activities to give protection during the Indonesian Migrant Workers and their family abroad. Protection during working is stated in Article 21 which includes:

a. Data collection and registration by the labor attache or pointed staff of foreign affair office;

b. Monitoring and evaluation of the Job Provider, job, and job condition;

c. Facilitating the fulfillment of Indonesian Migrant Workers' Right;

d. Facilitating the solution of labor cases;

e. Provision of counseling service;

f. Guidance, mediation, advocacy, and provision of legal assistance in the form of advocate service facility by the Central Government and/or the Representative of the Republic of Indonesia as well as guardianship according to the local country law;

g. Coaching on Indonesian Migrant Workers; and

h. Repatriation facility.

- Protection after working is all activities to give protection since the Indonesian Migrant Workers and their family arrive in Indonesia until they are back to their original region, including further service to become productive workers. Protection after working is stated in Article 24, which includes:

a. Facilitating the return until to the original region;

b. Settlement of Indonesian Migrant Workers' right which has not been fulfilled;

c. Facilitating the processing of Indonesian Migrant Workers who are sick and dead;

d. Social rehabilitation and reintegration; and 
e. Empowerment of Indonesian Migrant Workers and their family.

This protection is given to prevent the emergence of problem to Indonesian Migrant Workers who indeed are susceptible to occur even before departure until after working or returning from working abroad. This is due to that Indonesian Migrant Workers are still not good enough in terms of education and also come from regions whose experience is still minimal.

Far before Indonesia conducted an amendment on Regulation of Law number 39 of 2004 into Law number 18 of 2017, the Philippines' government has applied regulation focusing on migrant workers' protection. The regulation foundation of the Philippine to give protection to its workers is more advanced that Indonesia, since the migrant workers' protection is stipulated more comprehensively [42]. The regulation foundation of Philippine migrant workers is Migrant Workers and Overseas Filipinos Act of 1995. In addition, there is also another legal foundation focusing on improving the protection and ensuring the right and welfare of OFWs and Overseas Filipino, those are:

- An Act Instituting a "BALIKBAYAN PROGRAM", RA 06768.

- An Act Instituting a "BALIKBAYAN PROGRAM", RA 09174 Amendment.

- An Act Providing For A System Of Overseas Absentee Voting By Qualified Citizens Of The Philippines Abroad, Appropriating Funds Therefor, And For Other Purposes, Republic Act No. 9189.

- An Act Making The Citizenship Of Philippine Citizens Who Acquire Foreign Citizenship Permanent. Amending For The Purpose Commonwealth Act. No. 63, As Amended And For Other Purposes, Republic Act No. 9225.

- An Act To Institute Policies To Eliminate Trafficking In Persons Especially Women And Children, Establishing The Necessary Institutional Mechanisms For The Protection And Support Of Trafficked Persons, Providing Penalties For Its Violations, And For Other, Republic Act No. 9208.

- An Act Amending Republic Act Numbered 6768, Entitled, "An Act Instituting A Balikbayan Program" by Providing Additional Benefits And Privileges To Balikbayan And For Other Purposes, Republic Act No. 9174 [43].

Regulation of Migrant Workers and Overseas Filipinos Act of 1995, was formed aiming to take action in forming labor policy abroad and determining higher protection standard and welfare improvement for the migrant workers, their family and the Philippines abroad who are in distress or other objectives. In Migrant Workers and Overseas Filipinos Act of 1995, the Philippine will employ its workers abroad only in countries that ensure the protection of the Philippine migrant workers [44]. In Sec. 4 in Migrant Workers and Overseas Filipinos Act of 1995, stipulated the migrant workers' placement, stating "The State shall deploy overseas Filipino workers only in countries where the rights of Filipino migrant workers are protected. The government recognizes any of the following as a guarantee on the part of the receiving country for the protection and the rights of overseas Filipino workers:

a) It has existing labor and social laws protecting the rights of migrant workers;

b) It is a signatory to multilateral conventions, declarations or resolutions relating to the protection of migrant workers;

c) It has concluded a bilateral agreement or arrangement with the government protecting the rights of overseas Filipino workers; and,

d) It is taking positive, concrete measures to protect the rights of migrant workers." [45] From Sec.4, it can be seen that during the replacement, the Philippine government emphasized the protection, especially to the countries which employ the Philippine migrant workers. If it is compared to Indonesia, the migrant workers' protection becomes the focus only after the 
amendment of Law Number 39 of 2004 into Law number 8 of 2017, while Philippine has focused on protection since 1995 .

The difference between the protection in the Law Number 18 of 2017 and Migrant Workers and Overseas Filipinos Act of 1995, is in the sanction given if there are things which are not in accordance with the regulation. In Philippine regulation, penalty is given in detailed and clearly regarding the amount that must be paid and the length of time of the imprisonment. Meanwhile, in Indonesia regulation, it is not mentioned in detailed regarding the penalty given and such penalty is stipulated in derivative regulation which is Ministerial Regulation.

If it is analyzed deeper, the regulation which becomes the legal foundation in giving migrant workers' protection both in Indonesia and Philippine, it still does not discuss the use of technology in giving protection, even though Indonesia regulation is amended during the industrial revolution 4.0 era. This is still not a focus on the regulation of both countries despite the importance of the provision of migrant workers' protection which has become the focus of both countries. Considering Indonesia and Philippine as countries that send many migrant workers and a large amount of cases experience by the migrant workers, it is important to provide regulation which focuses on the protection.

Tabel 3. Comparative between Indonesia and Philipines based on Regulation Aspect to Protect Migrant Workers

\begin{tabular}{|c|c|c|}
\hline & Differences & Similarities \\
\hline Indonesia & $\begin{array}{l}\text { Penalty not mentioned in } \\
\text { detailed }\end{array}$ & \multirow{2}{*}{ 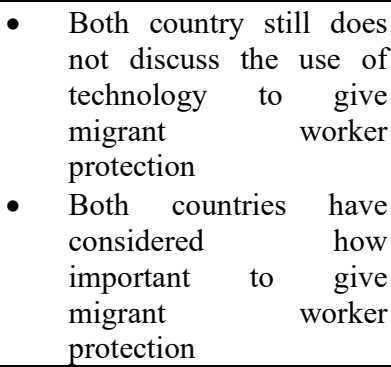 } \\
\hline Philipines & Penalty is given detailed and clearly & \\
\hline
\end{tabular}

Source: authors reference.

\section{Program of Migrant Workers' Protection in Industrial Revolution 4.0 era}

In the development of the industrial revolution 4.0 era, in order to give protection to the migrant workers, it can use Internet of Things or Digital Platform released in the form of policy issued by the government. The program initiated by the Non-Governmental Organization focusing on fulfilling the migrant workers' rights. The following discusses the program initiated by the government and non-governmental organization in Indonesia and the Philippine stated by Bassina Farbenblum, Laurie Berg, and Angela Kintominas (2018) in their paper entitled "Transformative Technology For Migrant Workers Opportunities, Challenges, And Risks" [31]. The program made by Philippine-based on technology to give protection are:

1. OWWA Electronic Case Registry and Response System (e-CARES)

Overseas Workers Welfare Administration (OWWA) of the Philippine has the role in managing the Emergency Repatriation Fund, pre-departure loan program and family assistance loan for the benefit of the workers who search for a job abroad. OWWA issues Case Electronic System and Response System (e-CARES) which is one of the digital platforms to receive a complaint from the migrant workers. ECARES system receives a complaint and classifies the complaint from the migrant 
workers which are given to the overseas post specifically regarding the complaint and the development of the case can be seen online by the migrant workers. E-CARES system stores database of Processing System Membership which amounted to more than 8 million of OWWA members and 23,197,187 detail of contract record of the OWWA members [47]. E-CARES system is also a place to store education program records on the migrant workers' pre-departure, assistance program and welfare service used, as well as help request (RFA) made if there is any complaint. E-CARES is in the form of cellular application system which can be used by OWWA member to see and verify their profile, update the OWWA membership, contact OWWA hotline, register to the program and welfare service online, and apply RFA online. From this application, migrant workers can have a digital card of OWWA OOFW which can be used to access the benefit and special right, automatically verify the membership detail, and the processing time is faster.

2. Philippines Overseas Employment Administration (POEA), Department of Labour and Employment Philippines

Philippines Overseas Employment Administration (POEA) of 2015 makes policy so that the private labor agent which already has license from POEA must have an active Facebook account and maintain it. Private agent which has a Facebook account must accept the request from the migrant workers to be able to contact or give direct complaint [31]. Such a policy is made since Facebook is one social media that is quite popular and easily accessed by anyone including the migrant workers.

3. My Labor Matters Verite Southeast Asia (VSEA), Center for Migrant Advocacy (CMA), Filipino Migrants Center, Energetic Green / TALL

My Labor Matters is a multi-channel communication platform for the worker and job applicator in Philippine Migration Corridor. This platform was made with the collaboration with the Center for Migrant Advocacy (CMA), Filipino Migrants Center, and Energetic Green/TALL. This platform is integrated with the official Facebook account of My Labor Matters. This platform aims to improve the safety and effect of online positive information sharing between the Philippine migrant workers who work abroad. This platform facilitated the worker to report complaints or problems through Facebook messenger, phone call or text messages. Furthermore, the complaint tracking will be performed by Verite and its partner based on an internal data basis. This platform also provides the most updated and relevant information for the worker and job applicator, as well as a place to share information and story regarding the workers' experience during their work abroad.

4. OFW Watch

OFW Watch is a platform which combines emergency assistance and social relationship facility as well as support for Overseas Filipino Worker abroad. This platform is initiated in 2014 by the Overseas Workers Welfare Administration/ Department of Labor and Employment. This platform facilitates the user to register through Facebook account and connected to the other Philippines which have the same geographical area, dialect, original city, and profession. OFW Watch can detect the workers who are not active in social media in a certain period of time, and sent the detection result as emergency notification for the user who is close with the nonactive users. This platform also gives feedback regarding the general news related to Philippine and updates the OFW Watch Facebook account in every country.

Program released by Indonesia based on technology to give protection are:

1. PJTKI (Recruitment Watch) Monitor Infest, Indonesia Launched 2014 
PJTKI (Recruitment Watch) monitor is a platform for Indonesia migrant workers, especially the female housemaid to assess the Indonesia recruitment agent. This platform is made in 2014 with the initiation from Tifa Foundation \& PSD-BM. This platform aims to (1) facilitate the access to discussion made by the user regarding the service quality offered by the recruitment agency to make it possible for the migrant to choose which recruiter they will use; (2) give incentive to recruiter to improve their performance; and (3) make it possible for the civil society to be involved in more informed advocacy directing to policy and recruitment industry monitor in national and local level [31]. In addition, it also make it possible for the migrant workers to review the discussion collected offline by Infest which cooperated with civil community organization to visit the female migrant both in the community and target country, who are then filtered so that they are not defiling a good name, to be published in PJTKI monitor platform. Every month, there are about 25 phone calls from migrant workers who search for information regarding recruitment agents or information regarding the recruitment process and workers' migration. In this platform, the recruitment agency is also involved to update the information to update their basic information about their agency and license status, upload their registration certificate, or also respond to the job complaint. This platform is supported by government instance to help and investigate the human trafficking even though Infest has recorded the platform, it will more affect it is correlated to the intervention at government level such as to permit regime.

2. Safe Travel

In 2018, the Ministry of Foreign Affair of the Republic of Indonesia releases Safe Travel application for all Indonesian people who are abroad including the Indonesian migrant workers. This application gives information regarding the safety rate of 180 countries in the world marked by color, restaurant, worship place, tourist object, currency rate, self-report, lost passport report, local Indonesian people community, to Indonesian Embassy Office in those hundred countries [46]. It is expected that through this application Indonesian People who have a problem can press the panic button provided in this application so that it can be detected by Indonesia Embassy abroad, and action can be made fast regarding the problem.

3. Recruitment Advisor International Trade Union Confederation (ITUC), with support from the ILO Fair Recruitment Initiative Launched 2018

In 2018, International Trade Union Confederation (ITUC) with the support from ILO Fair Recruitment Initiative, made a platform which is Recruitment Advisor. This platform facilitates the migrant workers to assess the recruitment agent, allows them to share their experience in the comment column, and learn about the migrant workers' rights. This web-based platform includes thousand recruitment agents from Hong Kong, Indonesia, Malaysia, Nepal, Philippine, Qatar, Saudi Arabia, Singapore, and other places. This platform is initiated with English, Indonesian, Nepali and Tagalog and its development to have more languages in accordance with the countries connected in this platform. This platform is promoted by workers union network and civil community organization in all countries to the migrant workers, with the initial target to involve the migrant workers directly to give input offline and upload in the form of sharing the migrant workers' experience. The government has the role of providing licensed recruitment agent list Singapura. In July 2018, the Recruitment Advisor has achieved 6,994 users and contained 3,024 review [31]. 
Based on those programs, both Indonesia and the Philippine have more platforms for migrant workers to improve the protection. Most of the platforms are the initiation result of government agency which has the task and function to give information regarding the placement and protection of migrant workers. This shows that the government has utilized the presence of digitalization which occurs due to industrial revolution 4.0. Most of the platforms is also a platform which accommodates information regarding licensed recruitment agency, migrant workers' experience and complaint given by the migrant workers when they encounter problem in the placement country.

\section{Conclusion}

The provision of protection for migrant workers is the main priority for the sending countries, both Indonesia and the Philippine. The protection given by the government of the Philippine and Indonesia has covered and focused on the migrant workers' protection. Indonesia issued regulation through Law Number 18 of 2017 about Migrant Workers' protection, while Philippine issued through Migrant Workers and Overseas Filipinos Act of 1995. If it is compared, Philippine regulation is more comprehensive that the Indonesia regulation which must have derivative regulation in its implementation. The result in using digitalization as migrant workers' protection means is shown by each country through the use of digital-based platform initiated by the government and non-governmental organizations. This digital platform is the forms of giving protection to the migrant workers in the industrial revolution 4.0 era. The provision of protection is done through based or application to share information regarding licensed recruitment agents to the complaint and suggestion if there is any problem faced by the migrant workers.

\section{Acknowledgment}

I would like to express my Dr. Lina Miftahul Jannah, S.Sos., M.Si, for her guidance and support me to write this paper. This paper also received support and providing from Policy, Governance and Administrative Reform (PGAR) Research Cluster at the Faculty of Administrative Sciences, University of Indonesia.

\section{References}

[1] Sastrohadiwiryo, B. Siswanto. (2003). Manajemen Tenaga Kerja Indonesia: Pendekatan Administratif dan Operasional. Jakarta: Bumi Aksara.

[2] International Organization for Migration (IOM). (2010). Migrasi Tenaga Kerja dari Indonesia: Gambaran Umum Migrasi Tenaga Kerja Indonesia di Beberapa Negara Tujuan di Asia dan Timur Tengah.

[3] Miroslav Lajčák. (2018). Why We Need A Global Understanding Of Migration. Retrieved from: https://www.weforum.org/agenda/2018/01/global-migration-can-be-a-success/ 
[4] IOM's Global Migration Data Analysis Centre (GMDAC). Labour migration. (2019). Retrieved from: https://migrationdataportal.org/themes/labour-migration

[5] Testaverde, Mauro., dkk. (2017). Migrating to Opportunity Overcoming Barriers to Labor Mobility in Southeast Asia By. Washington DC: World Bank Group https://openknowledge.worldbank.org/bitstream/handle/10986/28342/211106ov.pdf?seque nce $=19$

[6] Harima, Reiko. (2012). Restricted Rights Migrant women workers in Thailand, Cambodia and Malaysia. London: War On Want

[7] Badan Nasional Penempatan dan Perlindungan Tenaga Kerja Indonesia. (2019). Data Penempatan dan Pelindungan PMI Tahun 2018. Pusat Penelitian, Pengembangan dan Informasi (PUSLITFO).

[8] Phillippine Statistics Authority. (2018). Distribution of Overseas Filipino Workers by Place of Work and Sex.

[9] Sukesi, Keppi., Henny Rosalinda, dan Agustina Shinta Hartati W. (2017). Migrasi Perempuan, Remitansi dan Perubahan Sosial Ekonomi Pedesaan. Malang: Universitas Brawijaya Press.

[10] Bank Indonesia. (2019). Remitansi Tenaga Kerja Indonesia (TKI) Menurut Negara Penempatan (Juta USD).

[11] World Bank. Record High Remittances Sent Globally in 2018. (2019). Retrieved from: . https://www.worldbank.org/en/news/press-release/2019/04/08/record-high-remittancessent-globally-in-2018

[12] World Bank. Accelerated remittances growth to low- and middle-income countries in 2018. (2018). Retrieved from: https://www.worldbank.org/en/news/pressrelease/2018/12/08/accelerated-remittances-growth-to-low-and-middle-income-countriesin-2018

[13] Richard Eldridge, dkk. (2017). What does the Fourth Industrial Revolution mean for migration?. Retrieved from: https://www.weforum.org/agenda/2017/06/what-does-thefourth-industrial-revolution-mean-for-migration/

[14] McKenzie, Fiona. (2017). The Fourth Industrial Revolution and International Migration. Lowy Institute. Retrieved from: https://www.lowyinstitute.org/publications/fourthindustrial-revolution-and-international-migration\#_edn19

[15] Walwei, Ulrich. 2016. Digitalization and structural labour market problems: The case of Germany. International Labour Office.

[16] Mårten Blix. 2017. Digitalization, Immigration and the Welfare State. Edward Elgar Publishing.

[17] Chang, Jae-Hee and Phu Huynh. (2016). ASEAN In Transformation: The Future Of Jobs At Risk Of Automation. International Labour Office, Bureau for Employers' Activities ; ILO Regional Office for Asia and the Pacific. - Geneva: ILO, 2016 (Bureau for Employers' Activities (ACT/EMP) working paper ; No. 9)

[18] Global Information Society Watch. (2016). Economic, Social And Cultural Rights And The Internet.

[19] Alcácer, and Cruz-Machado. (2019). Scanning the Industry 4.0: A Literature Review on Technologies for Manufacturing Systems. Engineering Science and Technology, 22, 899919.

[20] Migrant CARE. (2019). Data Statistik Pendampingan Kasus Migrant CARE 2010-2018. 
[21] Juwarih. (2019). Marak Penipuan Bermodus Tawaran Kerja ke Luar Negeri, SBMI Berikan Tips Pencegahan. Retrieved from: http://www.liputanbmi.com/baca/3578/marakpenipuan-bermodus-tawaran-kerja-ke-luar-negeri-sbmi-berikan-tips-pencegahan

[22] Deutsche Welle Indonesia Official Site. (2018). Indonesia Tuntut Singapura Usut Kasus Perdagangan TKI via Toko Online. Retrieved from: https://www.dw.com/id/indonesiatuntut-singapura-usut-kasus-perdagangan-tki-via-toko-online/a-45535551

[23] Kurniawan, Figo. 2018. PRT Indonesia di Malaysia 'Diiklankan' di Facebook. Retrieved from: http://www.liputanbmi.com/baca/3038/prt-indonesia-di-malaysia-diiklankan-difacebook

[24] Pre, Maria Cristina. (2018). Beware Of Fake Overseas Jobs Posted On Facebook. Retrieved from: http://www.thefilipinocircle.com/2018/07/10/beware-of-fake-overseasjobs-posted-on-facebook/

[25] Irianto, Sulistyowati., dkk. (2011). Akses Keadilan dan Migrasi Global: Kisah Perempuan Indonesia Pekerja Domestik di Uni Emirat Arab. Jakarta: Yayasan Pustaka Obor Indonesia.

[26] Bhopal, Raj S. 2013. Migration, Ethnicity, Race, and Health in Multicultural Societies. Oxford: Oxford University Press.

[27] Kleiner, J. Robert 2003. Migration: Immigration and Emigration in International Perspective. Westport: Greenwood Publishing Group.

[28] Arisman and Ratnawati Kusuma Jaya. 2018. Protection of Human Rights and Labour Migration for Employment Purpose Across ASEAN. Jakarta: Center for Southeast Asian Studies (CSEAS).

[29] Ruhs, Martin and Bridget Anderson. 2010. Who Needs Migrant Workers?: Labour Shortages, Immigration, and Public Policy. Oxford: Oxford University Press.

[30] Lee, MinHwa, dkk. (2018). How to Respond to the Fourth Industrial Revolution, or the Second Information Technology Revolution? Dynamic New Combinations between Technology, Market, and Society through Open Innovation. Journal of Open Innovation: Technology, Market, and Complexity, 4(21), 1-24.

[31] Farbenblum, Bassina., Laurie Berg and Angela Kintominas. 2018. Transformative Technology For Migrant Workers Opportunities, Challenges, And Risks. New Work: Open Society Foundations.

[32] Rakasima, Mahmud Fadli, dkk. (2011). Lima Tahun BNP2TKI, Mengabdi dengan Cinta. Jakarta: Direktorat Sosialisasi dan Kelembagaan Penempatan Deputi Penempatan BNP2TKI.

[33] Azmy, Ana Sabhana 2012. Negara dan Buruh Migran Perempuan: Menelaah Kebijakan Perlindungan Masa Pemerintahan Susilo Bambang Yudhoyono 2004-2010. Jakarta: Yayasan Pustaka Obor Indonesia.

[34] Badan Nasional Penempatan dan Perlindungan Tenaga Kerja Indonesia. (n.d). Profil Sejarah. Retrieved from: http://www.bnp2tki.go.id/profil-sejarah

[35] Gonzalez, Joaquin Lucero 1998. Philippine Labour Migration: Critical Dimensions of Public Policy. Pasir Panjang Road: Institute of Southeast Asian Studies.

[36] Philippine Overseas Employment Administration (POEA). (2016). Discover the Top Countries of Deployment and Highest-Paying Jobs for OFWs. Retrieved from: https://www.workabroad.ph/article/98/Discover-the-Top-Countries-ofDeployment-and-Highest-Paying-Jobs-for-OFWs? 
[37] Philippine Overseas Employment Administration (POEA). 2018. Overseas Jobs and Salary 2019. Report Retrieved from: https://www.workabroad.ph/article/197/2018-Overseas-Jobs-and-Salary-Report

[38] Taylor, George R. 2005. Integrating Quantitative and Qualitative Methods in Research. University Press of America.

[39] Creswell, John W. 2014. Research Design: Qualitative, Quantitative, and Mixed Methods Approaches. California: SAGE Publication.

[40] Indonesian Law No. 39/2004 on the Placement and Protection Migrant Worker Indonesia.

[41] Indonesian Law No. 18/2017 on the Protection Migrant Worker Indonesia.

[42] Setyawati, D. (2013). Assets or commodities? Comparing regulations of placement and protection of migrant workers in Indonesia and the Philippines. ASEAS - Austrian Journal of South-East Asian Studies, 6(2), 264-280.

[43] Commission on Filipinos Overseas. n.d .Laws and Policies Affecting Overseas Filipinos. Retrieved from: https://cfo.gov.ph/aupair/2-uncategorised/19-laws-and-policiesaffecting-overseas-filipinos.html

[44] Padilla, Luzviminda G. (2011). Philippine Institutional and Legal Framework For Labor Migration. World Bank. Retrieved from: http://siteresources.worldbank.org/INTRUSSIANFEDERATION/Resources/3054 99-1109933291285/7676111306404779438/2011_05_17_PHILIPPINE_ENG.pdf

[45] Migrant Workers and Overseas Filipinos Act of 1995.

[46] International Labour Organization. (2018). Digitalization to promote decent work for migrant worker in ASEAN.

[47] CNN Indonesia. (2018). Aplikasi Wajib bagi WNI Selama di Luar Negeri. Retrieved from: https://www.cnnindonesia.com/gaya-hidup/20180416111544-269291057/safe-travel-aplikasi-wajib-bagi-wni-selama-di-luar-negeri 